\title{
Nilai Nutrisi Silase Limbah Sayur Kol dengan Penambahan Dedak Padi dan Lama Fermentasi yang Berbeda
}

\author{
Nutrition Value of Cabbage Vegetable Waste Silage with Rice Bran Addition and Different \\ Duration of Fermentation
}

\author{
S. Superianto, A.E. Harahap, dan A. Ali \\ Fakultas Pertanian dan Peternakan Universitas Islam Negeri Sultan Syarif Kasim Riau \\ Kampus Raja Ali Haji Jl. H. R. Soebrantas Km 15 Pekanbaru \\ Email : neniannisaharahap@yahoo.co.id
}

\begin{abstract}
The waste vegetable cabbage have high water degree that quickly experience decaying therefore one of alternative by used with silage. The purpose of researcher to know percentage of nutrition contained in silage the waste vegetable cabbage by increasing mixture in rice and long to fermentation be different. The researchused to completely randomized design with factorial system ( $2 \times 3)$. Factor A as additional level mixture of ricebran $0 \%$ and $35 \%$. The factor B is a long fermentation in nought day, seventh day and fourteen day. The parameter to measure is the dry, the coarse protein, coarse fat, dust and the extract without nitrogen. In the result mixture of the rice is $35 \%$ given to improving like the fact $(\mathrm{P}<0,01)$ toward the content of dry, coarse fat, dust and the extract without nitrogen. And no fact to improve $(\mathrm{P}<0,05)$. Long fermentation not influential real $(\mathrm{P}<0,05)$ toward the dry, coarse fat, fiber rude, and the extract without nitrogen. And give the influence to real $(\mathrm{P}<0,01)$ toward the dust. The best character contained in a certain level of additonal rice bran $35 \%$ and long fermenting namely 14 days seen from a decrease in the ashes of $11,38 \%$.
\end{abstract}

Keywords: Nutritional quality, silage, vegetable cabbage, fermentation

\begin{abstract}
ABSTRAK
Limbah sayur kol memiliki kadar air yang tinggi sehingga cepat mengalami pembusukan maka salah satu alternatif penggunaannya dengan silase. Penelitian ini bertujuan untuk mengetahui nilai nutrisi yang terkandung dalam silase limbah sayur kol dengan penambahan dedak padi dan lama fermentasi yang berbeda. Penelitian ini menggunakan Rancangan Acak Lengkap (RAL) Pola Faktorial (2x3) yaitu faktor A adalah level penambahan dedak padi $0 \%$ dan 35\%. Faktor B yaitu lama fermentasi 0 hari, 7 hari dan 14 hari. Parameter yang diukur adalah Bahan Kering (BK), Protein Kasar (PK), Lemak Kasar (LK), Abu dan Bahan Ekstrak Tanpa Nitrogen (BETN). Hasil penelitian menunjukan pemberian substrat dedak padi $35 \%$ memberikan pengaruh sangat nyata $(\mathrm{P}<0.01)$ terhadap kandungan Bahan Kering (BK), Lemak Kasar (LK), Serat Kasar (SK), Abu dan Bahan Ekstrak Tanpa Nitrogen (BETN). Tidak berpengaruh nyata terhadap terhadap kandungan Protein Kasar ( $\mathrm{PK})(\mathrm{P}>0.05)$. Lama fermentasi tidak berpengaruh nyata $(\mathrm{P}<0.05)$ Terhadap Bahan Kering $(\mathrm{BK})$, Lemak Kasar $(\mathrm{LK})$, Serat Kasar $(\mathrm{SK})$ dan Bahan Ekstrak Tanpa Nitrogen $(\mathrm{BETN})$ dan memberikan pengaruh sangat nyata $(\mathrm{P}<0.01)$ terhadap kandungan penurunan Abu. Perlakuan terbaik terdapat pada level penambahan dedak padi 35\% dan lama fermentasi 14 hari dilihat dari penurunan kandungan abu sebesar $11,38 \%$
\end{abstract}

Kata kunci: Kualitas nutrisi, silase, limbah sayur kol, fermentasi

\section{PENDAHULUAN}

Pencemaran lingkungan merupakan hasil yang ditimbulkan oleh tindakan aktifitas manusia yang menimbulkan perubahan langsung atau tidak langsung, pencemaran lingkungan ini akan menyebabkan dampak yang negatif seperti pencemaran yang dihasilkan kendaraan, limbah yang dihasilkan sampah organik, dan lain-lain. Pencemaran yang dihasilkan sampah di pasar merupakan salah satu masalah yang sering dialami masyarakat sekitar, hal ini pasar sebagai tempat transaksi jual beli barang bagi masyarakat dan aktifitas yang meningkat di pasar dapat meningkatkan limbah yang 
dihasilkan. Limbah yang dihasilkan pasar dapat menimbulkan dampak yang buruk bagi kesehatan warga pasar tersebut, seperti menimbulkan bau busuk, dan sebagai media tumbuh berbagai kuman penyakit, selain itu proses pembuangan dan pembersihan limbah memerlukan biaya yang mahal. Dwiyanto (2007) menyatakan bersih atau kotornya lingkungan sangat dipengaruhi oleh manusia yang berada di lingkungan itu. Permasalahan lingkungan ini menyangkut tentang pencemaran, baik pencemaran tanah, air, udara, dan suara (Rahayu dan Puji, 2010).

Pemanfaatan limbah sayur pasar sebagai alternatif penganti hijauan pakan ternak merupakan salah satu motivasi untuk menyediakan hijauan makanan ternak yang terbatas dimusim kemarau, penyediaan hijauan yang terbatas dimusim kemarau dapat menimbulkan dampak kepada produktifitas ternak. Menurut Sunarminto (2010) sukses tidaknya industri peternakan di Indonesia, khususnya industri ternak ruminansia tergantung pada beberapa faktor, salah satu faktor yang sangat penting adalah pengembangan tanaman untuk penyedian pakan utamanya yang berupa hijauan. Ternak ruminansia mempunyai keistimewaan karena memiliki mikroba di dalam rumen sehingga mampu memanfaatkan hijauan termasuk hijauan non kenvensional seperti limbah pasar sebagai pakan utama yang mudah diperoleh dan harga yang murah. Jadi seiring dengan meningkatnya kuantitas limbah hijauan asal pasar dan peningkatan jumlah ternak, ketika hijauan konvensional mengalami penyusutan akibat berkurangnya intensitas hujan atau musim kemaru, limbah hijauan asal pasar dapat menjadi pakan pengganti hijauan ruminansia, salah satunya limbah sayur pasar adalah sayur kol atau kubis. Kubis termasuk spesies Brassica olaracea, famili Cruciferae (Pracaya, 1994). Kubis (Brassica olaracea) merupakan sayuran daun yang cukup populer di Indonesia. Di beberapa daerah orang lebih sering menyebutnya sebagai kol dimana nama ilmiah kubis diberi nama Brassica olaracea, jenis kubis ini memiliki ciri-ciri daunnya saling menutup satu sama lain membentuk krop atau telur. Kubis mengandung air $>90 \%$ sehingga mudah mengalami pembusukan (Saenab, 2010).

Dedak padi merupakan limbah pengolahan padi menjadi beras dan kualitasnya bermacam-macam tergantung dari varietas padi. Dedak padi adalah hasil samping pada pabrik penggilingan padi dalam memproduksi beras. Menurut (Schalbroeck, 2001) produksi dedak padi di Indonesia cukup tinggi per tahun dapat mencapai 4 juta ton dan setiap kuwintal padi dapat menghasilkan 18-20 gram dedak, sedangkan menurut Yudono et al. (1996) proses penggilingan padi dapat menghasilkan beras giling sebanyak 65\% dan limbah hasil gilingan sebanyak 35\%, yang terdiri dari sekam 23\%, dedak dan bekatul sebanyak $10 \%$.

Iklim pancaroba dengan dua musim di Indonesia menjadikan proses pengeringan sulit dilakukan sehingga limbah sayuran mudah mengalami pembusukan yang berdampak pada pencemaran lingkungan. Kondisi tersebut menjadikan limbah sayuran lebih tepat jika diolah menjadi silase terlebih dahulu karena limbah sayuran berada dalam kondisi anaerob selama proses silase. Mengacu pada Perry et al. (2003) bahwa teknologi silase mampu mengurangi pemborosan hijauan, dapat dibuat 
dari hijauan yang kurang berkualitas, dan dapat dibuat pada beragam kondisi cuaca, maka teknologi silase yang diberikan sebelum limbah sayuran diolah menjadi bentuk pakan. Felly dan Kardaya (2011) menyatakan silase dari limbah pasar berupa kulit jagung 33,33\% + sawi putih $16,67 \%+$ kol 16,67\% + dedak $33,33 \%$ dari analisis proksimat diperoleh data kandungan bahan kering (86,57\%), kadar air $(61,27 \%)$, abu (26,46\%), protein kasar (7,51\%), lemak kasar (1,70\%), serat kasar (25,79\%).

Silase merupakan salah satu teknologi pengawetan dengan proses fermentasi, dengan teknik ini pakan yang melimpah di musim penghujan dapat disimpan lebih lama untuk kebutuhan pakan di musim kemarau (Mulyano,1998). Silase pakan sumber serat yang berasal dari limbah sayuran pasar merupakan pakan alternatif untuk mengganti hijauan pakan pada saat musim kemarau. Silase pakan dibuat dengan menggunakan penyimpanan secara anaerob sehingga diharapkan dapat disukai ternak (palatabel). Selain pengerjaanya mudah dan biaya murah, juga dapat meningkatkan kualitas dari pakan sehingga dapat diberikan dengan maksimal dan dapat mengatasi kelangkaan hijauan pada musim kemarau.

\section{BAHAN DAN METODE}

\section{Bahan dan Alat}

Penelitian ini telah dilaksanakan pada bulan April - September 2016 di Laboratorium Ilmu Nutrisi dan Kimia Fakultas Pertanian dan Peternakan Universitas Islam Negeri Sultan Syarif Kasim Riau Pekanbaru

Bahan yang digunakan untuk fermentasi Kulit Limbah Sayur Kol yang diperoleh dari pedagang gorengan kawasan Pasar Kampar dan dedak. Bahan untuk analisis proksimat adalah Aquades, $\mathrm{HCl}, \mathrm{K}_{3} \mathrm{SO}_{4}, \mathrm{MgSO}_{4}, \mathrm{NaOH}$, $\mathrm{H}_{3} \mathrm{BO}_{3}, \mathrm{H}_{2} \mathrm{BO}_{4}, \mathrm{CCl}_{4}$, Enter Benzen dan ditambah dengan Pelarut. Peralatan yang digunakan untuk fermentasi adalah timbangan, pisau, talenan, baskom, plastik hitam, dan selotip. Untuk a Alat yang digunakan untuk analisis prosimat diantaranya yaitu: pemanas, kjeltec, soxtec, fibertec, kertas saring, tanur listrik, tang crucible dan alat destilasi lengkap dengan erlenmeyer

\section{Metode Penelitian}

Penelitian menggunanakan rancangan acak lengkap (RAL) pola Faktorial yang terdiri dari 2 faktor yaitu Faktor A yaitu level dedak dengan taraf $0 \%$ dan 35\% serta Faktor B yaitu lama fermentasi dengan level 0 hari, 7 hari, dan 14 hari dengan 3 ulangan.

Peubah yang diukur adalah Bahan Kering $(\mathrm{BK} \%)$, Protein Kasar (PK\%), Lemak Kasar (LK\%), Serat Kasar (SK\%), Abu (\%)dan BETN (\%). Data yang diperoleh diolah secara statistik menggunakan Rancangan Acak Lengkap (RAL) (Steel dan Torrie, 1995). Bila terdapat perbedaan antar perlakuan dilakukan uji lanjut menggunakan Duncan's Multiple Range Test (DMRT)

\section{Prosedur Penelitian}

Limbah sayur terlebih dahulu dipotong 3 - $5 \mathrm{~cm}$ dengan menggunakan pisau kemudian dikeringkan pada ruang terbuka, setelah dikeringkan ditimbang kembali untuk melihat berat keringnya, selanjutnya limbah sayuran dikering anginkan dan dimasukkan kedalam oven sampai kadar airnya $60=70 \%$. Campuran 1000 gram limbah sayuran kol 
dengan 45 gram dedak dalam bak plastik. Limbah sayuran kol dan dedak dicampur kemudian disilase (fermentasi) selama 0,7 dan 14 hari.

\section{HASIL DAN PEMBAHASAN}

\section{Bahan Kering (BK)}

Rataan kandungan Bahan Kering (BK) silase limbah sayur kol dengan penambahan dedak padi disajikan pada Tabel 1

Tabel 1. Rataan kandungan bahan kering silase limbah sayur kol

\begin{tabular}{ccccc}
\hline Level dedak & \multicolumn{3}{c}{ Lama fermentasi ( hari) } & \multirow{2}{*}{ Rataan } \\
\cline { 2 - 4 }$\%$ & 0 & 7 & 14 & \\
\hline 0 & $47,18 \pm 4,63$ & $49,54 \pm 7,13$ & $51,99 \pm 1,90$ & $49,56 \pm 4,19^{\mathrm{a}}$ \\
35 & $81,10 \pm 7,16$ & $82,76 \pm 1,24$ & $78,03 \pm 2,21$ & $80,63 \pm 3,27^{\mathrm{b}}$ \\
\hline Rataan & $64,14 \pm 19,34$ & $66,15 \pm 18,76$ & $65,01 \pm 14,38$ & \\
\hline
\end{tabular}

Keterangan: Superskrip huruf yang berbeda pada kolom yang sama menunjukan perbedaan nyata ( $\mathrm{P}<0,05), \pm$ : menyatakan standar deviasi

Berdasarkan Tabel diatas bahan kering pada substrat akan memperlihatkan bahwa perlakuan penambahan mempengaruhi kadar bahan kering dari silase. dedak padi pada silase limbah sayur kol, Perbedaan lama fermentasi menunjukan memberikan pengaruh nyata $(\mathrm{P}<0,05)$ terhadap kenaikan kandungan bahan kering sedangkan lama fermentasi tidak berpengaruh nyata terhadap peningkatan kandungan bahan kering $(\mathrm{P}>0,05)$. Tidak terjadi interaksi antara level penambahan dedak padi dan lama fermentasi terhadap peningkatan kandungan bahan kering.

Terjadinya peningkatan bahan kering terhadap silase limbah sayur kol dengan penambahan dedak padi kemungkinan disebabkan oleh level pemberian dedak padi yang tinggi, karena didalam dedak padi memiliki nilai bahan kering yang tinggi sebesar 95,53\% sehingga semakin tinggi level pemberian dedak padi dapat meningkatkan kandungan bahan kering pada silase limbah sayur kol. Hal ini sesuai dengan yang dilaporkan oleh Zuprizal (2000) bahwa dedak padi memiliki bahan kering yang tinggi antara $86 \%$ - 92\%. Lebih lanjutnya Felly dan Kardaya (2011) juga menyatakan tingginya pengaruh tidak berbeda nyata $(\mathrm{P}>0.05)$ terhadap kandungan bahan kering. Hal ini kemungkinan diduga penurunan $\mathrm{pH}$ yang belum optimal pada perubahan kandungan bahan kering selama proses ensilase. Kondisi pH pada penelitian ini berkisar antara 4,165,69 yang memperlihatkan kategori sedang, sehingga belum mendukung pertumbuhan Bakteri Asam Laktat. Bakteri Asam Laktat akan tumbuh dan bekerja, melalui proses respirasi yang menghasilkan air. Menurut Risma (2015) kondisi pH yang berkualitas sedang 4,71 - 4,80 belum optimal dalam mendukung pertumbuhan Bakteri Asam Laktat (BAL), sehingga masih belum memberikan pengaruh terhadap perubahan bahan kering selama proses silase.

Kandungan bahan kering silase limbah sayur kol dengan penambahan dedak padi pada penelitian ini berkisar antara 47,17\% $82,75 \%$. Kandungan bahan kering ini lebih rendah dibandingkan dengan hasil yang 
dilaporkan oleh penelitian Felly dan Kardaya (2011) pada silase sayur pasar yang diperkaya dengan berbagai macam adiktif dan bakteri asam laktat yaitu kandungan bahan kering $86,57 \%$ - 91,64\% namun lebih tinggi dari pada penelitian yang dilaporkan oleh Risma (2015) pada kandungan nutrisi silase mahkota nanas yang difermentasi dengan penambahan berbagai level dedak padi yaitu $30,14 \%$ $32,18 \%$.

\section{Kandungan Protein Kasar}

Rataan kandungan protein kasar silase limbah sayur kolmasing-masing perlakuan dapat dilihat pada Tabel 2 di bawah ini.

Tabel 2. Rataan kandungan protein kasar silase limbah sayur kol

\begin{tabular}{|c|c|c|c|c|}
\hline \multirow{2}{*}{$\begin{array}{c}\text { Level dedak } \\
\%\end{array}$} & \multicolumn{3}{|c|}{ Lama fermentasi ( hari) } & \multirow{2}{*}{ Rataan } \\
\hline & 0 & 7 & 14 & \\
\hline 0 & $12.64 \pm 2.81$ & $11.76 \pm 3.48$ & $11.00 \pm 0.19$ & $11.79 \pm 2.08$ \\
\hline 35 & $8.98 \pm 1.02$ & $10.67 \pm 2.11$ & $9.59 \pm 2.80$ & $9.74 \pm 1.13$ \\
\hline Rataan & $10.81 \pm 2.75$ & $11.21 \pm 2.64$ & $10.29 \pm 1.94$ & \\
\hline
\end{tabular}

Keterangan: ( \pm ) menyatakan standar deviasi

Berdasarkan Tabel diatas memperlihatkan bahwa perlakuan penambahan dedak padi dan lama fermentasi pada silase limbah sayur kol tidak memberikan pengaruh nyata $(\mathrm{P}>0,05)$ terhadap kenaikan kandungan protein kasar dan tidak terjadi interaksi antara level penambahan dedak padi dan lama fermentasi terhadap peningkatan kandungan protein kasar.

Tidak terjadi kenaikan nilai protein kasar dengan pemberian level dedak padi yang berbeda diduga pertumbuhan BAL yang belum optimal. Hal ini berimplikasi terhadap penurunan kandungan protein kasar, yang ditandai dengan kondisi nilai $\mathrm{pH}$ yang berkategori sedang dengan nilai 4,16 - 5,69. Hal ini sesuai yang dinyatakan oleh Risma (2015) bahwa pH yang berkategori sedang kemungkinan belum optimal dalam mendukung perkembangan BAL di dalam silase dan belum tumbuh secara baik karena kondisi $\mathrm{pH}$ berkisar 4,71 - 4,80. Lebih lanjutnya Sandi et al (2010) menyatakan bahwa kualitas silase dapat digolongkan menjadi empat yaitu sangat baik $(\mathrm{pH} 3,2$ 4,2), baik ( $\mathrm{pH} \mathrm{4,2} \mathrm{-} \mathrm{4,5),} \mathrm{sedang} \mathrm{(} \mathrm{pH} \mathrm{4,5} \mathrm{-} \mathrm{4,8),}$ buruk $\quad(\mathrm{pH}>4,8) . \quad$ Macaulay

menambahkan $\mathrm{pH}$ 3,2 - 4,2 dimana BAL tumbuh pada kondisi asam.

Kandungan protein kasar pada silase limbah sayur kol dengan penambahan dedak padi pada penelitian ini berkisar antara $8,98 \%$ - 12,64\%. Kandungan PK ini lebih rendah dibandingkan dengan penelitian yang dilaporkan oleh Felly dan Kardaya (2011) pada silase sayur pasar yang diperkaya dengan berbagai macam adiktif dan bakteri asam laktat yaitu $3,56 \%-14,52 \%$

\section{Kandungan Serat Kasar}

Rataan kandungan serat kasar silase limbah sayur kolmasing-masing perlakuan dapat dilihat pada Tabel 3 di bawah ini. 
Tabel 3. Rataan kandungan serat kasar silase limbah sayur kol

\begin{tabular}{ccccc}
\hline \multirow{2}{*}{$\begin{array}{c}\text { Level dedak } \\
\%\end{array}$} & 0 & 7 & 14 & Rataan \\
\cline { 2 - 4 } & $19,67 \pm 3,5$ & $12,63 \pm 11,6$ & $11,42 \pm 1,6$ & $14,57 \pm 4,4^{\mathrm{a}}$ \\
\hline 0 & $26,00 \pm 3,61$ & $26,82 \pm 6,52$ & $21,99 \pm 5,64$ & $24,93 \pm 3,4^{\mathrm{b}}$ \\
\hline Rataan & $22,83 \pm 4,71$ & $19,73 \pm 11,46$ & $16,71 \pm 6,05$ &
\end{tabular}

Keterangan: Superskrip huruf yang berbeda pada kolom yang sama menunjukan perbedaan sangat nyata ( $\mathrm{P}<0,01)$, \pm : menyatakan standar deviasi

Hasil analisis ragam memperlihatkan cukup untuk merenggangkan ikatan lignoselulosa dan lignohemiselulosa yang bahwa perlakuan penambahan dedak pada silase limbah sayur kol memberikan pengaruh sangat nyata terhadap kandungan serat kasar $(\mathrm{P}<0,01)$ sedangkan lama fermentasi tidak berpengaruh nyata terhadap penurunan kandungan serat kasar $(\mathrm{P}>0,05)$. Tidak terjadi interaksi antara level penambahan dedak padi dan lama fermentasi terhadap penurunan kandungan serat kasar.

Kenaikan kandungan serat kasar pada perlakuan silase dengan penambahan dedak padi diduga disebabkan oleh level penambahan dedak padi yang tinggi karena didalam dedak padi memiliki nilai serat kasar sebesar 30,73\%, hal ini berimplikasi terhadap peningkatan kandungan serat kasar pada silase. Hal ini diperkuat oleh Zuprizal (2000) menyatakan bahwa kandungan serat kasar di dedak padi berkisar antara 6\%-30\%. Lebih lanjutnya Felly dan Kardaya (2011) menyatakan bahwa peningkatan serat kasar disebabkan oleh kandungan NDF dan ADF yang merupakan komponen dari serat kasar.

Kandungan serat kasar pada perlakuan lama fermentasi tidak berbeda nyata $(\mathrm{P}>0,05)$ diduga disebabkan $\mathrm{pH}$ pada penelitian ini dalam kategori sedang 4,16 - 5,69 sehingga kemampuan BAL yang belum optimal untuk menghasilkan asam laktat dalam jumlah yang merupakan komponen serat kasar, yang berakibatkan kandungan serat kasar tidak mengalami perubahan. Hal ini sama yang dilaporkan oleh Risma (2015) bahwa kondisi $\mathrm{pH}$ yang belum optimal pada BAL untuk menghasilkan asam laktat dalam jumlah yang cukup untuk merenggangkan ikatan lignoselulosa dan lignohemiselulosa sehingga BAL belum meyebabkan perubahan pada kandungan serat kasar silase. Lebih lanjutnya Sandi et al (2010) menyatakan bahwa kualitas silase dapat digolongkan menjadi empat yaitu sangat baik (pH 3,2 - 4,2), baik ( $\mathrm{pH} 4,2$ - 4,5), sedang ( $\mathrm{pH} 4,5$ - 4,8), buruk $(\mathrm{pH}>4,8)$. Macaulay (2004) menambahkan pH 3,2 - 4,2 dimana BAL tumbuh pada kondisi asam.

Kandungan serat kasar pada penelitian ini berkisar antara 11,42\% - 26,82\% lebih rendah dibandingkan penelitian yang dilaporkan oleh Felly dan Kardaya (2011) pada silase sayur pasar yang diperkaya dengan berbagai macam adiktif dan bakteri asam laktat yaitu 10,99\%-28,15\%,

\section{Kandungan Lemak Kasar}

Rataan kandungan lemak kasar silase limbah sayur kol masing-masing perlakuan dapat dilihat pada Tabel 4 di bawah ini. 
Tabel 4. Rataan kandungan lemak kasar silase limbah sayur kol

\begin{tabular}{ccccc}
\hline \multirow{2}{*}{$\begin{array}{c}\text { Level dedak } \\
\%\end{array}$} & 0 & 7 & Lama fermentasi ( hari) & \multirow{2}{*}{ Rataan } \\
\cline { 2 - 4 } & $0,65 \pm 0,28$ & $1,30 \pm 0,26$ & $1,15 \pm 0,27$ & $1,03 \pm 0,10^{\mathrm{a}}$ \\
\hline 0 & $2,64 \pm 0,60$ & $3,29 \pm 1,54$ & $2,77 \pm 0,73$ & $2,90 \pm 0,51^{\mathrm{b}}$ \\
\hline Rataan & $1,64 \pm 1,17$ & $2,30 \pm 1,47$ & $1,96 \pm 1,01$ &
\end{tabular}

Keterangan: Superskrip huruf yang berbeda pada kolom yang sama menunjukan perbedaan sangat nyata ( $\mathrm{P}<0,01)$, \pm : menyatakan standar deviasi

Berdasarkan Tabel diatas memperlihatkan bahwa perlakuan penambahan dedak padi pada silase limbah sayur kol memberikan pengaruh sangat nyata $(\mathrm{P}<0,01)$ terhadap kenaikan kandungan lemak kasar sedangkan lama fermentasi tidak berpengaruh nyata terhadap peningkatan kandungan lemak kasar $(\mathrm{P}>0,05)$. Tidak terjadi interaksi antara level penambahan dedak padi dan lama fermentasi terhadap peningkatan kandungan lemak kasar.

Terjadi peningkatan kadar lemak kasar pada silase limbah sayur kol dengan penambahan dedak padi disebabkan oleh level pemberian dedak padi yang tinggi karena didalam dedak padi memiliki nilai lemak kasar sebesar 4,67\%. Hal ini berimplikasikan bahwa semakin banyak level penambahan dedak padi akan meningkatkan kandungan lemak kasar pada silase. Akbarillah et al (2005) menyatakan bahwa kadar lemak kasar di dedak padi berkisar 5,50\% - 7,62\%. Untuk lebih lanjutnya Felly dan Kardaya (2011) juga menyatakan semakin tinggi level pemberian aditif silase berupa dedak padi dan limbah sayuran seperti kol, akan meningkatkan kandungan lemak kasar silase.

Sedangkan lama proses fermentasi tidak berpengaruh nyata $(\mathrm{P}>0,05)$ tarhadap kadar lemak kasar. Hal ini diduga perkembangan bakteri masih berada di fase log yaitu fase pembelahan sel yang dimana pembelahan sel yang lambat yang disebabkan pemanfaatan substrat dedak dan sayur kol yang belum optimal, sehingga BAL yang tumbuh masih sedikit. BAL yang tumbuh belum sampai ke fase pertumbuhan cepat yang berimplikasikan belum terjadi pemecahan lemak didalam bahan pakan menjadi asam lemak dan gliserol, dimana untuk pertumbuhan mikroba membutuhkan sebagian asam lemak. Menurut Mucra (2007) perlakuan fermentasi bertujuan memecah senyawa kompleks menjadi lebih sederhana agar bisa dimanfaatkan oleh mikroba untuk pertumbuhannya sebagai sumber energi dalam bentuk VFA (Vollaile Fatty Acid) selain energi dari karbohidrat mudah tercerna.

Kandungan lemak kasar pada penelitian ini berkisar antara 0,65\% - 3,29\% lebih tinggi dibandingkan penelitian yang dilaporkn oleh Felly dan Kardaya (2011) pada silase sayur pasar yang diperkaya dengan berbagai macam adiktif dan bakteri asam laktat yaitu $0,12 \%$ $1,70 \%$

\section{Kandungan Abu}

Rataan kandungan abu silase limbah sayur kol masing-masing perlakuan dapat dilihat pada Tabel 5 di bawah ini. 
Tabel 5. Rataan kandungan abu silase limbah sayur kol

\begin{tabular}{ccccc}
\hline Level dedak & \multicolumn{3}{c}{ Lama fermentasi ( hari) } & \multirow{2}{*}{ Rataan } \\
\cline { 2 - 4 }$\%$ & 0 & 7 & 14 & \\
\hline 0 & $6.36 \pm 1.50^{\mathrm{Aa}}$ & $10.00 \pm 0.63^{\mathrm{Ab}}$ & $7.17 \pm 0.94^{\mathrm{Aa}}$ & $7.84 \pm 0.35$ \\
35 & $14.38 \pm 1.07^{\mathrm{Bb}}$ & $13.26 \pm 0.59^{\mathrm{Bb}}$ & $11.38 \pm 0.64^{\mathrm{Ba}}$ & $13.01 \pm 0.64$ \\
\hline Rataan & $10.37 \pm 4.55$ & $11.63 \pm 1.87$ & $9.28 \pm 2.50$ & \\
\hline
\end{tabular}

Keterangan: Superskrip huruf yang berbeda pada baris dan kolom yang sama menunjukan perbedaan sangat nyata $(\mathrm{P}<0,01)$ superskrip pada baris dengan huruf besar (faktor $\mathrm{B}$ ), superskrip pada kolom dengan huruf kecil (faktor A), \pm : menyatakan standar deviasi

Berdasarkan Tabel diatas sawi putih dan dedak maka semakin tinggi memperlihatkan bahwa interaksi antara level juga kadar abu.

dedak dengan lama fermentasi pada silase

Wibowo (2010) menyatakan bahwa limbah sayur kol memberikan pengaruh sangat nyata $(\mathrm{P}<0,01)$ terhadap kandungan abu.

Terjadi penurunan kandungan abu pada perlakuan lama fermentasi 14 hari dengan penambahan level dedak padi 35\% sebesar $11,38 \%$. Hal ini diduga BAL memanfaatkan kandungan mineral anorganik seperti $\mathrm{Ca}, \mathrm{P}$, $\mathrm{Mg}$ yang berasal dari dedak padi dan limbah sayur kol karena proses fermentasi sehingga meyebabkan kandungan abu pada interaksi terjadi penurunan. Menurut Barokah (2015) bila bahan anorganik (abu) turun hal ini diduga kandungan bahan organik yang mengandung zat-zat nutrisi yang cukup penting semakin meningkat.

Sedangkan level penambahan dedak padi terjadi peningkatan kandungan abu diduga level pemberian dedak padi yang tinggi dikarenakan kadar abu pada dedak padi tinggi sebesar 18,37\%. Pendapat ini sama dengan pernyataan Felly dan Kardaya (2011) menyatakan bahwa pemberian jerami dan penambahan bahan aditif ikut mempengaruhi kandungan abu silase, semakin tinggi persentase pemberian jerami, kulit jagung, kadar SK dan kadar Abu mempunyai hubungan positif, tingginya kadar SK akan berpengaruh terhadap besarnya kadar abu bahan dan sebaliknya. Abu merupakan komponen anorganik yang tersusun dari bermacam mineral seperi $\mathrm{Ca}, \mathrm{P}, \mathrm{Mg}$ dan lainnya.

Kandungan abu pada penelitian ini berkisar antara 6,36\% - 14,38\% lebih rendah dibandingkan penelitian yang dilaporkan oleh Felly dan Kardaya (2011) pada silase sayur pasar yang diperkaya dengan berbagai macam adiktif dan bakteri asam laktat yaitu 2,52\% $26,46 \%$.

\section{Kandungan BETN}

Rataan kandungan BETN silase limbah sayur kol masing-masing perlakuan dapat dilihat pada Tabel 6 . Berdasarkan Tabel diatas memperlihatkan bahwa perlakuan penambahan dedak padi pada silase limbah sayur kol memberikan pengaruh sangat nyata $(\mathrm{P}<0,01)$ terhadap kandungan BETN sedangkan lama fermentasi tidak berpengaruh nyata terhadap peningkatan kandungan BETN dan tidak 
terjadi interaksi terhadap level penambahan dedak dan lama fermentasi $(\mathrm{P}>0,05)$.

Tabel 6. Rataan kandungan betn silase limbah sayur kol

\begin{tabular}{ccccc}
\hline \multirow{2}{*}{$\begin{array}{c}\text { Level dedak } \\
\%\end{array}$} & \multicolumn{3}{c}{ Lama fermentasi ( hari) } & \multirow{2}{*}{ Rataan } \\
\cline { 2 - 4 } & \multicolumn{1}{c}{0} & \multicolumn{1}{c}{7} & 14 & \\
\hline 0 & $60.69 \pm 6.77$ & $64.31 \pm 10.08$ & $69.26 \pm 2.45$ & $64.75 \pm 3.60^{\mathrm{b}}$ \\
35 & $47.99 \pm 3.10$ & $45.96 \pm 4.65$ & $54.27 \pm 3.39$ & $49.40 \pm 0.23^{\mathrm{a}}$ \\
\hline Rataan & $54.34 \pm 8.40$ & $55.13 \pm 12.26$ & $61.76 \pm 8.63$ &
\end{tabular}

Keterangan: Superskrip huruf yang berbeda pada baris dan kolom yang sama menunjukan perbedaan sangat nyata $(\mathrm{P}<0,01)$ superskrip pada baris dengan huruf besar (faktor $\mathrm{B}$ ), superskrip pada kolom dengan huruf kecil (faktor A), \pm : menyatakan standar deviasi

Penurunan kandungan BETN pada level penambahan dedak padi diduga $\mathrm{pH}$ pada penelitian ini termasuk kategori sedang 4,165,69 yang meyebabkan kinerja BAL belum optimal dalam memanfaatkan kandungan substrat yang ada di silase limbah sayur kol dengan penambahan dedak. Hal ini berimplikasi bahwa belum optimalnya pemanfaatkan kandugan substrat di silase sehingga mempengaruhi kandungan BETN. Hal ini diperkuat oleh Santi et al. (2011) menyatakan bahwa bakteri asam laktat mempunyai kemampuan untuk memfermentasikan gula menjadi asam laktat. Lebih lanjutnya Risma (2015) menyatakan bahwa asam laktat yang meyebabkan perombakan kandungan nutrisi di silase.

Lama fermentasi tidak berbeda nyata $(\mathrm{P}>0,05)$ terhadap kandungan BETN diduga perkembangan BAL masih berada di fase lag yaitu fase pertumbuhan dan perlu penyusuaian dengan lingkungan baru sehingga bakteri yang tumbuh masih sedikit. Pertumbuhan BAL yang masih belum maksimal meyebabkan pemanfaatan nutrisi pada bahan pakan juga tidak sempurna sehingga berimplikasi tidak adanya perubahan kandungan BETN yang dihasilkan. Hal ini diperkuat oleh Risma
(2015) menyatakan pertumbuhan BAL yang belum maksimal mempengaruhui kandungan nutrisi di silase. Lebih lanjutnya Tillman (1989) menyatakan bahwa faktor yang mempengaruhi perhitungan BETN yaitu BK, PK, SK dan abu.

Kandungan BETN pada penelitian ini berkisar antara 45,96\% - 69,26\% lebih tinggi dibandingkan penelitian yang dilaporkan Risma (2015) pada kandungan nutrisi silase mahkota nanas yang difermentasi dengan penambahan berbagai level dedak padi adalah $47,63 \%$ - 52,50\% dan penelian yang dilaporkan Barokah (2015) pada silase pelepah kelapa sawit dan indegofera sampai level 60\% bekisar 49,94\% - 57,00\%.

\section{KESIMPULAN}

Level penambahan dedak padi sebesar $35 \%$ dapat meningkatkan kandungan bahan kering, serat kasar, lemak kasar dan abu sedangkan terjadi penurunan terhadap kandungan protein kasar dan BETN. Lama fermentasi menurunkan kandungan abu pada perlakuan ke-14 hari yaitu 11,38\%. 


\section{DAFTAR PUSTAKA}

Akbarillah, T., Hidayat, \& T. Khoiriyah. 2007. Kualitas dedak dari berbagai varietas padi di Bengkulu Utara. Jurnal Sain Peternakan Indonesia. 2 (1) : 36-41.

Dwiyatmo, K. 2007. Pencemaran Lingkungan dan Penanganannya. PT. Citra Aji Parama. Yogyakarta.

Felly, S., dan Kardaya, D. 2017. Evaluasi kualitas silase limbah sayuran pasar yang diperkaya dengan berbagai aditif dan bakteri asam laktat. Jurnal Pertanian. 2(2) :117-124.

Mulyono, S. 1998. Teknik pembibitan kambing dan domba. Penebar Swadaya. Jarkarta.

Rahayu dan T. Puji. 2010. Enskilopedia Seri Desa-Kota. Aneka Ilmu.Semarang.

Perry, T. W., E. C. Arthur, dan S. L. Robert. 2003. Feeds and Feeding. Prentice Hall. New Jersey (USA).

Risma, E. 2015. Kandungan nutrisi silase mahkota nanas yang difermentasi dengan penambahan berbagi level dedak. Skripsi Jurusan Peternakan. Universitas Negeri Sultan Syarif Kasim Riau. Pekanbaru.

Tillman, A. D., H. Hartadi., S. Reksohadiprodjo, dan S Lebdosoekojo. 1989. Ilmu Makanan Ternak Dasar. Gadja Mada University Press. Yogyakarta.
Sandi, S., E. B. Laconi, A. Sudarman, K. G. Wiryawan, dan D. Mangundjaja. 2010. Kualitas nutrisi silase berbahan baku singkong yang diberi enzim cairan rumen sapi dan Leuconostoc mesenteroides.

Media Peternakan. 33(1): 25-30.

Santi, R. K. D., W. P. S. Widyawati, dan Suprayogi. 2011. Kualitas dan nilai nutrisi Kecernaan in-vitro silase Batang Pisang (Musa paradiseaca) dengan Penambahan Akselator. Jurnal Tropical Animal Husbandry. $1(1): 15-23$

Shcalbroeck. 2001. Toxicologikal evalution of red mold rice. DFG - senate comision on food safety. Ternak Monogastrik. Karya Ilmiah. Fakultas Peternakan Institut Pertanian Bogor, Bogor.

Saenab, 2010. Evaluasi pemanfaatan limbah sayuran pasar sebagai pakan ternak ruminansia di DKI Jakarta. Balai Pengkajian Teknologi Jakarta.

Sunarminto, B. H. 2010. Pertanian terpadu untuk mendukung kedaulatan pangan nasional. BPFE. Yogyakarta

Yudono, B. F. Oesman, dan Hermansyah. 1996. Komposisi asam lemak sekam dan dedak padi. Majalah Sriwijaya. 32 (2) 8-11.

Zuprizal. 2000. Komposisi kimia dedak padi sebagai bahan pakan lokal dalam ransum ternak. Buletin Peternakan Edisi Tambahan. $282-286$ 